\title{
How can we know the existence of God: Anselm and Aquinas?
}

\author{
Author: \\ Chibuikem C. Nnaeme ${ }^{1}$ \\ Affiliation: \\ ${ }^{1}$ Health Economics and HIV \\ and AIDS Research Division, \\ University of Kwazulu-Natal, \\ Westville Campus, \\ South Africa \\ Correspondence to: \\ Chibuikem Nnaeme \\ Email: \\ nnaemec@ukzn.ac.za \\ Postal address: \\ 54 Bank Terrace, Manor \\ Garden, Durban, South Africa \\ Dates: \\ Received: 08 June 2015 \\ Accepted: 28 Aug. 2015 \\ Published: 26 Nov. 2015 \\ How to cite this article: \\ Nnaeme, C.C., 2015, 'How \\ can we know the existence of \\ God: Anselm and Aquinas?', \\ Verbum et Ecclesia 36(1), Art. \\ \#1486, 6 pages. http://dx.doi. \\ org/10.4102/ve.v36i1.1486

\section{Copyright:} \\ (C) 2015. The Authors. \\ Licensee: AOSIS \\ OpenJournals. This work is \\ licensed under the Creative \\ Commons Attribution \\ License.
}

Read online:

Scan this QR

code with your

smart phone or

mobile device

to read online.
This article is concerned with how we can know about the existence of God. In attempting to do this, the article will single out two medieval thinkers, Anselm and Aquinas, and will examine their stances on the subject. The former holds, as exemplified in his ontological proof, that human beings can rationally know the existence of God, whilst the latter objects to the former's claim by proffering that human beings can know God's existence through effects of God's creation. Over the years these positions have appealed to people who defend either strand of the argument. Such a followership makes worthwhile my efforts to contribute to the ongoing debate. It is my intention to show the argument of each of these positions and indicate which is more plausible to human beings. It is vital to note that Anselm and Aquinas both accept the existence of God; therefore, the existence of God is not in question for them. The article will only concentrate on where the two thinkers differ in terms of how human beings can know God's existence.

Intradisciplinary and/or interdisciplinary implications: This article challenges idealists' philosophy that human beings can prove God's existence from the concept, God, as epitomised by Anselm's ontological argument. The critique of the argument through the application of Aquinas's realism exposes the limitedness of the human beings in epistemological conception of the absolute metaphysical reality.

\section{Introduction}

In the first section, the article will set the scene by putting Pseudo-Dionysius and his conception of the negative way as one of the attempts to offer the conception of God that is proper to human nature. The second section will engage with Anselm's ontological proof of the existence of God. It should be noted in this section the assumption that human beings can know and prove God's existence from the concept - God, is upheld. The third section will present Aquinas in contrast to Anselm. Aquinas's realism is pronounced in asserting that human beings cannot know God's existence unaided by sensible realities. This article acknowledges that there are diverse epistemological positions that contrast to Aquinas's position; however, they are beyond the scope of this article. The crux of the article is that human knowing about God's existence proceeds from experience of realities to the idea, and not vice versa (Stumpf 1975:174).

\section{The via negativa}

\section{The difficulty in predicating about God's existence}

Ever since the ancient and medieval epochs of philosophy there have been debates amongst philosophers and theologians concerning the existence of, and attributes that should be ascribed to, God. This is particularly difficult as human knowledge emanates from experience, ${ }^{1}$ and God cannot be said to be a reality that can be rationally accessed by human beings as other sensible realities. It is in this light that Boethius postulates the philosophic principle that all knowing necessarily proceeds according to the mode of the knower (Boethius 1963:117). Aquinas echoes the same principle by avowing that 'the mode of knowledge follows the nature of the knower' (S.T.1.Q.12. A.4.). Secondly, creatures which serve as effects through which we postulate God as the ultimate cause do not adequately represent the perfection which is in God. In a sense, one can say that there is a vast gulf between the powers of human knowledge and God's existence. This disparity is demonstrated in the incorporeality and immateriality of God as against the corporeal and material nature of human beings. At first, it sounds as if there is nothing human beings can know about God. This has been the basis of agnosticism. ${ }^{2}$ Is scepticism the solution to

1.That all human knowledge arises from experience means that human knowing accrues from realities which one comes across in daily living.

2.A belief that things within a particular sphere are unknowable; for example, the view that we cannot know whether or not God exists (Mautner 1996:7). 
the incomprehensibility of God? However, neither scepticism nor agnosticism can deter human curiosity in this regard.

Aquinas avers that God in self is supremely knowable. Though, what is supremely knowable in itself may not be knowable to a particular intellect such as human beings. For instance, God who is completely self-comprehensive is only partially comprehensible to human beings. It does not follow that God cannot be known at all, but that God exceeds every kind of knowledge, which means that God is not comprehended (S.T.1.Q.12. A.1). Human beings only know God partially because the knowledge of God's existence is beyond their grasp; thus, it is impossible that created human beings should comprehend God (S.T.Q.12. A.7.).

The difficulty was a concern for generations of neo-Platonists that nothing should be predicated of the supremely divine which might not, in any way, circumscribe the divine existence. This suggests that God is placed even beyond being, or at least 'declaring that to say that God is, is not to say of God anything which tells us what God is' (Evans 1994:55). In other words, the medieval period of philosophy created a legacy of sensitivity about predicating anything concerning God's existence. One of the solutions to this problem is to avoid making any affirmative predications about God. Such a stance is due to a belief in the ultimate inaccessibility of God to human knowing (Evans 1994:57).

\section{Pseudo-Dionysius and via negativa}

The concept via negativa was officially introduced to the philosophy of religion in the late 5th century by an anonymous author who wrote under the name Dionysius the Areopagite, also called Pseudo-Dionysius. He called himself Dionysius and claimed to be a disciple of St. Paul, but historians agree that his claim is false as he might also have been a Syrian contemporary of Boethius, whose writings must be dated around the year 500 A.D. Some authors argue that he claimed to be Dionysius, a disciple of Paul, probably to give authority to his philosophical and theological input into the study of the existence of God (Pieper 1960:47).

However, attention must be given to the inroads he made by postulating via negativa as one of the ways of predicating God's existence. ${ }^{3}$ According to Pseudo-Dionysius, the inaccessibility or incomprehensibility of God is not a result of the limitation of the human beings only, but a quality of God. Pseudo-Dionysius (1987), commenting in the Divine Names on God's incomprehensibility, asserts that:

No words can describe it, and it is of a kind that neither intelligence nor speech can lay hold of it, nor can it at all be contemplated since it surpasses everything and is wholly beyond our capacity to know it. (592d-593a)

For this reason, Pseudo-Dionysius (1987:614a) holds that the incomprehensibility of God is beyond every assertion and

3.The author notes that there are other ways of predicating the existence of God such as by affirmation, analogy and others, but focuses only on via negativa. denial. But he avers that denial statements are the closest human intellect can come towards God.

Pseudo-Dionysius (1987) suggests that:

We should posit and ascribe to the Supreme Being all the affirmations we make in regard to beings, and, more appropriately, we should negate all these affirmations, since the Supreme Being surpasses all being. (1000b)

However, he warns that we should not mistake the negations simply as opposites of the affirmations because the cause is prior and beyond every denial and assertion (PseudoDionysius 1987:1000b). ${ }^{4} \quad$ Luibheid (Pseudo-Dionysius 1987:136) ${ }^{5}$ who translated Pseudo-Dionysius' work interprets the aforementioned position as a mark that shows that Pseudo-Dionysius refutes the impression that negations can directly grasps God's existence.

Pseudo-Dionysius is aware that human beings unavoidably develop anthropomorphic conceptions of God, and for this reason he undertakes to remove from God all that can be predicated of creatures. This seemingly ingrained character in human beings is called anthropomorphism. ${ }^{6}$ Copleston (1950:95) argues that anthropomorphism is eliminated through via negative. The only positive aspect of human knowledge about God is that we do not know what God is like because God's existence exceeds human comprehension (Pieper 1960:52; Stumpf 1975:162). The negative way allows one to predicate with certainty something about God, though one's predication is negative. However, an excessive application of via negativa may lead to denial of God's existence. Or worse still, it may lead one to deny that the human being can at least establish the existence of God through effects, even though it cannot pry into what God is. It is essential to note that Pseudo-Dionysius holds that God's essence is unknowable even through the negative way. Referring to God's existence, he (Pseudo-Dionysius 1987) says that:

There is no speaking of it, no name, no knowledge of it. We make assertions and denials of what is next to it, but never of it, for $\mathrm{He}$ is both beyond every assertion and denial. (p. 1048b)

\section{Anselm's ontological argument Anselm}

Anselm (1033-1109) was born in Aosta in northern Italy. The archbishop of Canterbury is mainly remembered for his proof of God's existence in the Proslogion. ${ }^{7}$ Before this proof, Anselm sets out five proofs on the existence of God in his Monologion (Sherry 1987:42). Unsatisfied with the arguments in the Monologion, he searched for a single argument that

\footnotetext{
4.Pseudo-Dionysian assertion on negation is against Aristotle's insistence (on Interpretation 17a 31-33) that negations are opposites of affirmations (PseudoDionysius 1987:137).
}

5.Luibheid is the editor of Pseudo-Dionysius Complete Works.

6.It means attributing to God or other beings outside the sphere of human qualities as if they are in the category of human beings.

7.Proslogion is St. Anselm's work in which he wrote his ontological argument on the existence of God. 
would prove that God really exists, that God is the supreme good that needs no other and whom all things need for their existence and well-being (Anselm 1998:82). Ever since the medieval epoch there have been debates about what human beings can know about God's existence, bearing in mind the fact that what an agent can know is based on the agent's mode of being. Thus, it is logical to think that the human beings cannot rationally know God's existence expect through experience of sensible realities. But Anselm seemed to ignore this epistemological position.

\section{Ontological argument}

In this argument, Anselm (1998:83) claims to write from the vantage point of one who raises his mind in contemplation to God, one who searches for the intellectual understanding of what one believes. Anselm thinks that human beings can rationally without the aid of created reality know the existence of God. Anselm (1998:84) thus invites one to enter into the chamber of one's soul in order to find God. Following this invitation is the famous argument whose exponents claim proceeds from faith. It reads:

We believe that 'You's are something than which nothing greater can be thought. Neither can it be that a thing of such a nature does not exist [...] since the fool said in his heart, there is no God. (Anselm 1998:87)

Anselm (1998:87) insists that 'that than which nothing greater can be thought' exists necessarily in a manner that the fool even understands what he hears - that God is that than which nothing greater can be conceived, and what he understands is in his mind, even if he does not understand that it actually exists. Anselm postulates that the reality under discussion is an entity that exists not only in the mind, but also in actuality. He uses a painter and his planned art work as an analogy to one who denies the simultaneous existence of God both in the mind and in reality. He argues that the planned work exists in the mind of the artist and in reality though the artist does not know that the art exists actually as well till he executes the plan. Anselm (1998:87) supposes that "'that than which a greater" cannot be thought cannot exist in the mind alone since it can be thought to exist in reality also, which is greater'. It is notable to identify that, so far, Anselm's argument starts from concept of God's existence to an actual correspondence in reality. In other words, his proof starts from an idea and necessarily extends to reality (Stumpf 1975:174). He also thinks that it is impossible and self-contradictory to think that the idea in question does not necessarily exist both as an idea and in reality (Anselm 1998:88). He is so certain of this proposition in a way that this being in question truly exists in a manner that it cannot even be thought not to exist.

\section{Gaunilo objections}

Gaunilo was the first to identify the flaws in the Proslogion. In responding on behalf of the fool, Gaunilo starts with 8.'You' in this instance refers to God.
Anselm's assumption that the fool understands what he hears. Gaunilo poses the following question:

Could I not say that all kinds of unreal things, not existing in themselves in any way at all, are equally in the mind since, if anyone speaks about them, I understand whatever is said. (Anselm 1998:105)

When this object had been spoken of and heard, it could not be thought not to exist in the same way in which God cannot be thought not to exist. Gaunilo asks why Anselm puts forward this whole argument against anyone denying or doubting the existence of God if God's existence is undeniable (Anselm 1998:106).

Taking a cue from Augustine, Gaunilo suggests that the example of the painter having the picture he is about to make already in his mind does not support the Proslogion argument. This is because the picture, before it is actually made, is only an art of the painter which exists in the painter's understanding (Anselm 1998:106-107). To drive home his objection, Gaunilo posits a similar argument to the Proslogion, which any person that supports the validity of the latter argument may find hard to deny.

Gaunilo's parallel argument reads as follows: there is a perfect island in an ocean - it is a nonexisting reality which can be imagined in the mind. The perfect island has priceless pearls in abundance. Rumour has it that its richness surpasses the other lands which human beings inhabit. What is said of the perfect island is easily understood. But one cannot go on to say: you cannot doubt that this island, that is more excellent than all other lands, truly exists somewhere in reality than you can doubt that it is in your mind. This is because it is more excellent to exist not only as an idea alone but also in reality. Thus, this island exists in reality as well as in the mind if the Proslogion argument is valid (Anselm 1998:109).

\section{Anselm' s response to Gaunilo}

Anselm responds to Gaunilo's objections by contending that, if the reality in question can be thought of, it necessarily exists. For 'that than which a greater cannot be thought' cannot be thought save as being without a beginning. But whatever can be thought as existing and does not actually exist cannot be thought as not having a beginning of its existence. Consequently, 'that than which a greater cannot be thought' cannot be thought as existing and yet not actually exist (Anselm 1998:111-112). If anyone says that he thinks that this being does not exist, 'I reply that, when he thinks of this, either he thinks of something than which a greater cannot be thought, or he does not think at all' (Anselm 1998:115). The distinguishing characteristic of God's existence is that God's nonexistence cannot be conceived (Anselm 1998:116). The crux of this proof is that what is spoken of and understood must necessarily exist in thought and actuality; in this case, God. In regard to Gaunilo's parallel argument, Anselm replies that 'we can move from an idea to its necessary existence in only one 
case: in the case of that Being whose nonexistence cannot be thought' (Anselm 1998:121). But he said almost nothing on why the move from idea to necessary existence should be made only in reference to the God's existence.

There are other notable classical objections to ontological argument from Emmanuel Kant and David Hume. Kant (Mautner 1996:303) contends that existence is not a 'real predicate', especially when a concept has been defined in terms of 'real predicates', because the question concerning whether the concept predicated refers to something in existence is contestable. Similarly, Hume insists that propositions affirming existence are contingent and not necessary (Mautner 1996:303).

\section{Theological versus philosophical characters of ontological argument}

The supporters of theological character of ontological argument hold that Anselm's argument has nothing whatsoever to do with a proof of God. They see the Proslogion as an endeavour that has nothing to do with philosophy (Bouillard 1968:66). A major exponent, Karl Barth, widely expressed support in his Fides Quaerens Intellectum. Barth infers that the prayerful context, the audience, introduction and the purpose of the argument to insist on the theological character of the Proslogion argument, and that 'Anselm does not intend to deduce revealed truth from human premises. His ratio presupposes authority' (Bouillard 1968:69-73).

Barth (1931:64) observes that Fides Quaerens Intellectum is a search to understand what one already believes. This 'proof' presupposes faith and proceeds from faith (Barth 1931:64). Thus, it is through faith that Anselm successively proves the existence of God and his perfections (Bouillard 1968:75). Anselm's:

[...] proof for the existence of God is itself a rational knowledge which is not aware of its truth except within the understanding of the theologian and within the framework of a theology. (Bouillard 1968:78)

Therefore, the Proslogion argument is not a philosophical argument that tends to prove the existence of God; for this reason, it should not be open to philosophical analysis and critique.

However, philosophers such as Etienne Gilson and Pieper insist that the ontological argument has philosophical character and should be evaluated as philosophical attempt to prove the existence of God. This is partly informed by the observation that Anselm did not feel that he had been misunderstood when Gaunilo took the Proslogion to be a rational line of argument which he tried to refute (Bouillard 1968:85; Pieper 1960:71). The Proslogion is principally written to prove through necessary reason and without making an appeal to authority (Pieper 1960:76). Ontological argument strongly suggests a philosophical character in the sense that Anselm intended to formulate a demonstration valid in the eyes of everyone, including the unbeliever (Evans 1994:51;
Pieper 1960:71). Even the use of the term 'understand', which is mostly associated with philosophy, is pronounced throughout the Proslogion (Bouillard 1968:82-84).

\section{Anselm and the via negativa}

Pieper identifies Anselm as one of the medieval philosophical and theological thinkers who remained untouched by Pseudo-Dionysius's negative way (Pieper 1960:55). This is echoed by Anselm's willingness to find an argument for the existence of God which is free from scripture and authority, but based solely on reason (Pieper 1960:61). Pieper recognises two ways through which human reason can be overvalued. The first is the overvaluation of experience. The second is the overvaluation of logical deduction from general principles. He further states that the second is linked to Platonic tradition, and it is this deductive rationalism which Anselm conjured up in his Proslogion (Pieper 1960:61).

\section{Aquinas's realism}

According to Aquinas, there are two kinds of intellect: angelic and human. The latter abstracts the intelligible form from the sensible objects it perceives. The faculty of understanding is proportioned to the reality known. The proper object of the human intellect is the natures of visible things by which it arrives at some knowledge of things invisible (ST.1.84. A.7).

However, considering that human intellect is rooted in corporeal matter - the body - it follows logically that it knows only what has a form in matter. Due to our corporeality, our natural knowledge begins from the senses. Thus our knowledge can proceed as far as it is led by sensible things. Meanwhile, the human intellect which is united to the body cannot be led by sense so far as to grasp God's existence. This is because the sensible effects of God do not equal the power of God as their cause. Hence, through the knowledge of sensible things, the power of God cannot be known; nor can his existence be comprehended. But because the sensible things are his effects that depend on their cause, we can be led from them so far as to know of God, whether he exists, and to know of him what must necessarily belong to him, as the first cause of all things. The human intellect cannot comprehend God so as to know 'what it is'; however, it can investigate 'whether it is' (S.T.1.Q.12. A.12.).

\section{Is God's existence self-evident?}

Anselm asserts that the existence of God is self-evident not only to God but also to every human being. It can equally be deduced that he emulated St. Augustine's view that the knowledge of God is obviously innate in every human mind (Augustine Confession 1961. 10.8). Anselm supports Augustine's position through his attempt to postulate a rational and compelling proof of the existence of God that is independent of authority or faith. The manner in which he began his highly celebrated ontological argument displays his utter confidence in human reason to grasp God's existence. Referring to these thinkers, Gilson (1993) states that: 
Some thinkers consider the existence of God to be self-evident by holding that, since the desire of man naturally tends towards God as man's ultimate end, the existence of God must of necessity be known of itself. (p. 58)

This consists in showing that we possess a natural knowledge of it; self-evident means that something has no need of being proved; that it is undeniable (Gilson 1993:58). One may ask what the need is of seeking for a single proof for the existence of God if such existence is self-evident to everybody. Something that is self-evident needs no proof, as it is readily evident for all to perceive. It is pertinent to note that selfevident is a concept that has implication for both Anselm and Aquinas. The difference is in the application, whilst the form thinks that God's existence is self-evident to every human being including a 'fool', the latter insists that God's existence is only self-evident to God and not to human beings who has to infer God's existence from experience of sensible realities.

Descartes' proof of God's existence is also categorised as ontological argument because its starting point is the concept of God (Mautner 1996:65), and he avers that God's existence is self-evident. Descartes argues that we can think of the Idea of God only because a real God exists. And God is the cause of such an Idea in every human being. He also argues that we have a clear and distinct Idea of God (Descartes 1953:159). Hence, there must be some cause of our Idea of God. In addition, the cause of such an Idea must be as perfect as the Idea itself. Thus, the cause of our Idea of God can only be God himself (Lavine 1989:104-105). However, Antoine Arnauld identified the circularity of Descartes' argument (Mautner 1996:65).

Augustine, in referring to the innate Idea of God in humans, says that God instilled in each soul something that propels the soul to continually seek for the fulfilment in God (Augustine Confession 1961. 9.4). One obvious feature amongst Augustine, Anselm, Malebranche, Descartes and others who assert that the existence of God is self-evident is their readiness to attribute perfections to God. They even see no reason to demonstrate the existence of God because, for them, it is lucid enough (Copleston 1960:196-197).

In response to the idea of the innate Idea of God, Aquinas insists that human knowledge of reality proceeds from sensible objects to intellection of the sensible experiences. In other words, there is nothing in the intellect which is not first in the senses. He denies that we possess an innate knowledge of God's existence. For him what is innate in us is not this knowledge, but only the principle which will allow us to work back to God, as first cause, by reasoning from effects (Gilson 1993:58). Gilson (1993:99) highlights the fact that 'the divine existence exceeds in its immensity everything that the human mind can grasp; therefore, we cannot claim to know this existence, nor, consequently, start from it in our enquiry'.

Aquinas holds that a reality can be said to be self-evident in either of two ways: on the one hand, self-evident in itself, though not to us humans; on the other hand, self-evident because the predicate is included in the existence of the subject as 'bachelor is an unmarried man'. However, there is no reason to hold that God's existence is self-evident to us because we do not know the subject and predicate of the proposition, 'God exists', is beyond the human knowing faculty (S.T.1.Q.2. A.1.).

Aquinas claims that if, however, there are some to whom the existence of the predicate and subject is unknown, the proposition will be self-evident in itself, but not to those who do not know the meaning of the predicate and subject of the proposition. In addition, it is in Aquinas's mind that 'no one can mentally think the opposite of what is selfevident'; however, the opposite of the proposition 'God exists' can be mentally thought (S.T.1.Q.2. A.1.). Therefore, the proposition, 'God exists', is of itself self-evident, for the predicate is the same as the subject; because God is his own existence. But, we do not know the existence of God, the proposition is not self-evident to us, but can only be demonstrated by things that are known to us. Then, if God's existence is not self-evident to human beings, how do we demonstrate God's existence?

\section{Demonstration of the existence of God}

It is worthy to note that Anselm and others who subscribe to notions of the self-evident existence of God do not necessarily see the need to demonstrate the existence of God a posteriori. ${ }^{9}$ Their demonstration of God is a priori ${ }^{10}$ (Mautner 1996:24). In other words, they assume that the cause, God, is obviously known to every mind. Therefore, there is no need to prove God's existence via effect as the Cause is overt to everyone. The demonstration of the existence of any reality can be done either a priori or a posteriori. This follows on the principle that there is no effect without a cause. On this ground, Aquinas postulates that demonstration of the existence of God must be done a posteriori as we easily sense the effects of sensible things which have God as their ultimate cause. Aquinas (1947) thinks that:

From every effect the existence of its proper cause can be demonstrated, so long as its effects are better known to us; because since every effect depends upon its cause, if the effect exists, the cause must pre-exist. (S.T.1 Q.2. A.2.)

Hence, the existence of God, in so far as it is not self-evident to us, can be demonstrated from the effects, creatures which are known to us; though from them we cannot perfectly know God's existence (S.T.1Q.2. A.2.).

\section{Conclusion}

This article has attempted to contribute to the never-ending debate on how we can know about God's existence. The first section explained via negativa, highlighted the advantages and dangers that might ensue if it is exclusively employed.

\footnotetext{
9 A posteriori knowledge or truth claims are those which based on dependent on, or derived from, experience; reasoning from consequence to ground (Mautner 1996:24).

10.A priori refers to mode of reasoning from ground (what is earlier known) to consequences (Mautner 1996:25).
} 
The nub of the second section is Anselm's strong conviction about the power of reason, as expressed in his ontological argument, to directly know the existence of God. However, the objections raised against Anselm by Gaunilo expose the flaws in Anselm's over-confidence in human reason. In the third section Aquinas set out to correct Anselm's position. This article has attempted to show that human knowledge about God's existence proceeds from experience of realities to conception, and not vice versa because God's existence is not self-evident to human beings as it is to itself. It is my hope that this article will prompt a modest and proper use of human reason as opposed to extravagant and wild application that stretches beyond the bounds of reason as exemplified in ontological argument.

\section{Acknowledgements Competing interests}

The author declares that he has no financial or personal relationships which may have inappropriately influenced him in writing this article.

\section{References}

Anselm, 1998, Anselm of Canterbury: The major works, Oxford University Press, Oxford. Aquinas, T., 1947, Summa theologica, vol. II, transl. Fathers of the English Dominican Province, Benziger Brothers, New York.

Augustine, 1961, Confessions, transl. R.S. Pine-Coffin, Penguin Books, London. Barth, K., 1931, Fides Quaerens Intellectum, Pittsburgh, Munich.

Boethius, A.M.S., 1963, The consolation of philosophy, Centaur Press, Arundel.

Bouillard, H., 1968, The knowledge of God, transl. S.D. Femiano, Herder and Herder, New York.

Copleston, F., 1950, A history of philosophy, vol. II, Burns \& Oates Ltd., London.

Copleston, F., 1960, A history of philosophy, vol. IV, Burns \& Oates Ltd., London.

Descartes, R., 1953, A discourse on method, The Walter Scott Publishing Co. Ltd., London.

Evans, G.R., 1994, Philosophy \& theology in the Middle Ages, Routledge, London.

Gilson, E., 1993, The philosophy of St. Thomas Aquinas, transl. E. Bullough \& G.A. Elrington, Barnes \& Noble Books, New York.

Lavine, T.Z., 1989, From Socrates to Sartre: The philosophic quest, Bantam Books, New York.

Mautner, T., 1996, Dictionary of philosophy, Blackwell Publishers Ltd., Oxford.

Pieper, J., 1960, Scholasticism, Faber and Faber Ltd., London.

Pseudo-Dionysius, 1987, The complete works, transl. C. Luibheid, Paulist Press, New York. Sherry, P. (ed.), 1987, Philosophers on religion, Geoffrey Chapman, London.

Stumpf, E.S., 1975, Socrates to Sartre: A history of philosophy, 2nd edn., McGraw-Hill Book Company, New York. 